\title{
Interaction of Static Magnetic Fields (SMF) with Biology of Tetranychus urticae Koch (Acari)
}

\author{
Fatma S. Ali*; A. M. Hussein ${ }^{* *}$ and K. E. Rady ${ }^{* * *}$ \\ "Dept. of Zoology and Agric., Nematology, Fac. of Agric., Cairo Univ., Giza, Egypt. \\ ${ }^{* *}$ Plant Protec. Res. Institute, ARC, Dokki, Giza, Egypt. \\ ${ }_{* * *}^{*}$ Engineering Basic Sciences Dept., Fac. of Eng., Menufia Univ., Shebin El Kom, Egypt.
}

\begin{abstract}
A laboratory experiment was conducted to study the effects of Bio-assay of the economic mite; Tetranychus urticae Koch by the levels of static magnetic field forces. Completely randomized experiment with three replicates was designed. Similar groups of eggs of T. urticae were exposed to the odd numbers of magnets ; 1,3 and 5 units ( $0.14-4.0$ ml.t. ) and even numbers of magnets; 2,4 and 6 ( 2.6-4.24 ml.t. ). Check was left without magnetizing. The observations included, egg hatchability percentage, incubation period, life cycle, longevity, life span, survivability, mean number of eggs / female and sex ratio of the $1^{\text {st }}$ generation. Results showed that there was a linear negative relationship between the force of magnetic field and the percentage of egg hatchability. Hatching eggs were decreased from $100 \%$ in the check to $90.3 \%$ in 6 magnet unit's treatment. Also mean number of eggs and longevity decreased from 4.0 eggs \& 16.9 days to 2.3 eggs \& 11.4 days; while incubation period and life cycle were prolonged depending on the number of magnet pieces from 7.0 $\& 15.7$ days to $8.4 \& 12.0$ days, respectively of the above-mentioned magnets exposure.
\end{abstract}

Key words: Magnetic field, Biology, Tetranychus urticae.

\section{INTRODUCTION}

By the present time there are extensive researches which show the influence of weak magnetic fields (MF) on processes of embryonic development of various species of animals.

The effects of magnetic fields induction are different in nature and magnitude from the interaction of materials with static magnetic fields. Investigation of weak magnetic fields action on insects and microorganisms is carried out for the last dictates in different countries (Yim and Jeony, 2006). The magnetic fields affect yeast growth (Kimball, 1938), bacteria sensitivity (Jihen et al., 2010) protozoa and other microorganisms orientation (Brown 1962 and Jin et al., 2006).

The effects of magnetic fields on arthropods specially insects were studied by Levenegood and Shinkle, 1960 and Biljana et al., 2001 on Drosophila size of wing, Aphid molting, development and fecundity (Haline et al., 1964 and Juan He et al., 2012 and Giraldo et al., 2013 ), activity and aging of honeybees (Martin et al., 1988), behavior (Leucht,1984). Mosquito egg hatching (Pan and Liu, 2004) and egg hatchability and development of four economic insects (Hussein et al., 2014) and metamorphosis of the meal worm beetle (Ermakov and Ledven, 2010), orientation of insects (Maeda et al., 2008 ; Geo \& Zhai, 2010 and Paz et al., 2012 ) . The magnetic fields also affect chordates; fishes behavior (krylov et al., 2013), orientation of reptiles and bird's migration (Schneider et al., 1994) and some mammals development and growth like mice (Bamathy, 1963 a, b \& c; Bellossi, 1986 and Sathon et al., 1996). Effects of magnetic fields were also studied on snails orientation and metabolism (Brown et al., 1959; Brown \& Hultrer, 1960 and Brown \& Webb, 1960). Reports on the effect of magnetic fields on plants were found on seed germination and growth (pitman, 1963 \& 1964; Ginzo \& Decima, 1995 and Wang et al., 2008). About mites, no available references so far have been obtained in literature on the effects of magnetic fields interaction with mite biology of Tetrunychus urticae Koch, which is considered the most famous and destructive acari pest to economic crops and protected houses.

The aim of this investigation was to study the effects of static magnetic fields as one of the new approaches to control phytophagous mites. Effects of different levels of static magnetic fields on T. urticae development, fecundity, hatchability and sex ratio of the first generation were studied.

\section{MATERIALS AND METHODS}

As the eggs of pests represent the weakest stage along their life cycles, this lab. experiment aimed to investigate the effect of the magnetic fields on the hatchability, life cycle, fecundity and sex ratio of $T$. urticae Koch first generation individuals.

T. urticae were collected from castor leaves Ricinus communis L. from the farm of Faculty of, Agriculture, Cairo University.

Individuals of $T$. urticae were mass- reared in the laboratory on fresh leaves of Acalypha (Acalypha marginata) arising on moisten cotton wool in aluminum trays $(30 \times 20 \times 7 \mathrm{~cm})$ provided with water. 
Tangle-foot of mixture of Canada balsam and both castor and citronella oils surrounding the edges of the tray was applied to prevent the mite from escaping.

The trays were supplied with enough individuals of $T$. urticae different stages under room conditions. Water was added when needed to maintain suitable moisture. Groups from 25 eggs T. urticae were transferred to Acalypha. Leaf discs ( $2 \times 5 \mathrm{~cm}$ diameter) placed on cotton bed in Phil dish $20 \times 15 \mathrm{~cm}$ ). The cotton bed was kept wet by soaking with water twice daily so that the discs remained fresh. Ten $T$. urticae adult females collected from the laboratory stock cultures were transferred to each disc for laying eggs.

For Experiments on effect of magnetic field on $T$. urticae biology, 30 newly deposited eggs of the same age were transferred to a leaf disc $(2 \times 5 \mathrm{~cm})$. Every dish contained $0,1,2,3,4,5,6$ magnets. Dishes of the odd numbers of magnets 1,3 and 5 were fixed along the first generation besides the control (without magnetic field). T. urticae reared dishes of the even numbers of magnets 2, 4 and 6 magnets, also fixed besides another dish as a control. For both the important bio- assay parameters: egg hatchability, life cycle, longevity, fecundity and survival rate were calculated.

Three replicates from each treatment dishes were kept in room condition with temperatures $\left(22+2^{\circ} \mathrm{C}\right)$ and $65+5 \%$.R.H.

The used magnets were fixed around the dishes of mite rearing by the four directions (front, back, left and right sides ). All magnets used were completely similar in their magnetic field (14-16 mlt.) for each. Values of magnetic flux density in the center of dishes were measured using Tesla meter (TM204) apparatus manufactured by MCP lab. Electronics company, China. The magnetic field for each rearing dish was measured in 2 directions: The first when nodal of the apparatus parallel with (front - back) direction and the second with (left - right) direction. The 2 values and their average were calculated (Table 1).

\section{RESULTS AND DISCUSSION}

Table (1) indicates to the two measured values of the magnetic flux density for each treatment as well as their calculated average value. The table indicated to a positive relationship between numbers of magnet pieces and the magnetic field (ml.t.). The average values ranged between $0.14 \mathrm{ml}$.t. to $4.25 \mathrm{ml}$.t., when one magnet piece to 6 pieces of magnets were used, in comparison with the control treatment which had no magnet pieces and zero MF, Table 1 . It is important to have a clear idea of what magnetism means, magnetism is the attraction of one object to another. This applies to anything with any mass, including people. Although everything has a magnetic field, only metal can be magnetized when an object is not magnetized. The charge it contains appears something like instable, when an object is magnetized, its electrons are aligned in lines. An object has a charge when all of its electrons are aligned in the same direction. Also, this gives a magnet two poles, a north pole and a south pole. If one attempts to put two north poles or two south poles together, they will not connect. North is only attracted to south and vice versa (Rosanna, 2012).

Table (2) shows the values of the different bioassay parameters of the treatments affected with the odd numbers of magnet pieces 1, 3 and 5 magnets. Results showed that, each of the life cycle of $T$. urticae as well as incubation period of eggs were positively influenced by the presence of magnets number. All other measured parameters were negatively influenced with increasing the magnets pieces.

In respect of eggs, it was noticed that numbers of eggs per female under 1,3 and 5 magnet pieces decreased to $3.8,2.7$ and 3.1 eggs /female respectively in comparison with 4 eggs in the control. In the same time eggs hatchability percentage decreased to $60,54.5$ and $75.8 \%$ in comparison with $100 \%$ in the control. In the contrary, eggs incubation period increased under the same pre-mentioned treatments to $13.66,12.45$ and 10.33 days in comparison with only 7.0 days in the control. Our results are coming along with those of Hussein et al., 2014, who reported that four economic insects; Sitotroga ceralella, Trichogramma evanescens. Spodoptera littoralis and Spodoptera exigua percentage of egg hatchability was in linear negative relationship with the force of the magnetic field. The life cycle considerably increased to 28.6, 25.7 and 23.7 days respectively in comparison with 18.4 days in the control. In verse, the calculation of the life span indicated that there was slight decrease as it recorded $32.7,33.5$ and 33.8 days in comparison with 35.1 days for the control.

Both longevity and survivability recorded decrease in their values when the magnet numbers increased. Longevity values recorded only $3.5,7.8$ and 10.1 days in comparison with 16.7 days in the control. Survivability percentage recorded only 34.5 , 76.6 and $39.5 \%$; while it was $100 \%$ in the control.

Table (2) also, indicates that the abundance of $T$. urticae females decreased in the pre-mentioned treatments as the sex ratio recorded 66,51 and $60 \%$, respectively; while it was $87 \%$ in the control 
Table (1): The measured magnetic flux density in the investigated treatments

\begin{tabular}{lccccccc}
\hline $\begin{array}{c}\text { No. of magnet pieces } \\
\text { MF values }\end{array}$ & Control & $\begin{array}{c}\text { One } \\
\text { magnetizer }\end{array}$ & $\begin{array}{c}\text { Two } \\
\text { mags. }\end{array}$ & $\begin{array}{c}\text { Three } \\
\text { mags. }\end{array}$ & $\begin{array}{c}\text { Four } \\
\text { mags. }\end{array}$ & $\begin{array}{c}\text { Five } \\
\text { mags. }\end{array}$ & $\begin{array}{c}\text { Six } \\
\text { mags. }\end{array}$ \\
\hline $1^{\text {st }}$ direction & 0 & 0.17 & 5 & 7 & 10 & 7.5 & 8 \\
\hline $2^{\text {nd }}$ direction & 0 & 0.10 & 0.2 & 1.6 & 1.5 & 0.5 & 1.5 \\
\hline$(\underline{\ddot{x}})$ average value & 0 & 0.14 & 2.6 & 4.30 & 5.75 & 4.0 & 4.25 \\
\hline
\end{tabular}

Table (2): Effect of odd magnetizer on biological parameters of Tetranychus urticae Koch

\begin{tabular}{lcccccccc}
\hline $\begin{array}{c}\text { Parameter } \\
\text { Treatments }\end{array}$ & $\begin{array}{c}\text { Matchability } \\
\%\end{array}$ & $\begin{array}{c}\text { Incubation } \\
\text { period (days) }\end{array}$ & $\begin{array}{c}\text { Life cycle } \\
\text { (days) }\end{array}$ & $\begin{array}{c}\text { Longevity } \\
\text { (days) }\end{array}$ & $\begin{array}{c}\text { Life span } \\
\text { (days) }\end{array}$ & $\begin{array}{c}\text { No of } \\
\text { eggs/9/day }\end{array}$ & $\begin{array}{c}\text { Survivability } \\
\%\end{array}$ & $\begin{array}{c}\text { Sex } \\
\text { ratio \% }\end{array}$ \\
\hline Control & 100 & $7.0 \pm 1.92$ & $\mathbf{1 5 . 7 \pm 3 . 0 2}$ & $16.9 \pm 1.87$ & $32.6 \pm 3.6$ & $4.0 \pm 0.9$ & 100 & 86.2 \\
\hline One magnetizer & 60 & $13.7 \pm 2.59$ & $28.6 \pm 2.07$ & $3.5 \pm 0.96$ & $32.1 \pm 2.8$ & $3.8 \pm 1.4$ & 34.5 & 66 \\
\hline Three mags. & 54.5 & $12.5 \pm 2.13$ & $25.7 \pm 3.41$ & $7.8 \pm 1.54$ & $33.5 \pm 3.1$ & $2.7 \pm 0.7$ & 76.6 & 51 \\
\hline Five mags. & 75.8 & $10.3 \pm 1.96$ & $23.7 \pm 2.96$ & $10.1 \pm 1.76$ & $33.8 \pm 4.2$ & $3.1 \pm 0.9$ & 39.5 & 60 \\
\hline
\end{tabular}

Table (3): Effect of even magnetizer on biological parameters of Tetranychus urticae Koch

\begin{tabular}{lcccccccc}
\hline $\begin{array}{c}\text { Parameter } \\
\text { Treatments }\end{array}$ & $\begin{array}{c}\text { Matchability } \\
\%\end{array}$ & $\begin{array}{c}\text { Incubation } \\
\text { Period (days) }\end{array}$ & $\begin{array}{c}\text { Life cycle } \\
\text { (days) }\end{array}$ & $\begin{array}{c}\text { Longevity } \\
\text { (days) }\end{array}$ & $\begin{array}{c}\text { Life span } \\
\text { (days) }\end{array}$ & $\begin{array}{c}\text { No of } \\
\text { eggs / / / day }\end{array}$ & $\begin{array}{c}\text { Survivability } \\
\%\end{array}$ & $\begin{array}{c}\text { Sex } \\
\text { ratio \% }\end{array}$ \\
\hline Control & 100 & $7.0 \pm 1.92$ & $15.7 \pm 3.02$ & $16.9 \pm 1.87$ & $32.6 \pm 3.61$ & $4.0 \pm 0.9$ & 100 & 86.2 \\
\hline Two magnetizer & 88.3 & $14.0 \pm 3.13$ & $18.7 \pm 2.69$ & $10.0 \pm 2.23$ & $28.7 \pm 3.34$ & $2.6 \pm 0.9$ & 100 & 59.4 \\
\hline Four mags. & 62.5 & $12.7 \pm 2.97$ & $14.6 \pm 3.11$ & $17.0 \pm 2.45$ & $31.5 \pm 2.96$ & $2.9 \pm 0.8$ & 62.5 & 60.7 \\
\hline Six mags. & 90.3 & $8.4 \pm 2.35$ & $12.0 \pm 1.78$ & $11.4 \pm 2.35$ & $23.4 \pm 3.14$ & $2.3 \pm 0.4$ & 75.0 & 65.2 \\
\hline
\end{tabular}

treatment. The environmental effects of magnetic field are becoming of increasing importance, the interaction of the electromagnetic field with a biological system is complex (Barnothym, 1964). Static magnetic fields (SMF) as a type of environmental pressure are capable of affecting a number of biological systems (Arthur, 2003). The influence of SMF-s -treated on aphid Sitobion avenae indicated to a significant negative effect on survival rate, fecundity and life expectancy under the exposure of $0.176 \mathrm{~T}$ for $30 \mathrm{~min}$. and $0.065 \mathrm{~T}$ for $60 \mathrm{~min}$. (Juan He 2012).

Nabeel, 2010 studied the effect of magnetic field on the number of eggs of the two mites; Polyphagotarsonemus latus and T. urticae. The number of eggs was highly affected by the time of exposure. These results give us an idea that the magnetic field may be enhancing some metabolic enzymes inside the mites.

Data in Table (3) indicated to the values of prementioned parameters under treatments of the even numbers of magnet pieces 2, 4 and 6 magnets, in comparison with the control (OMF). The same trend of influence was noticed, number of eggs per female decreased to 2.6, 2.9 and 2.3 eggs in comparison with 4.0 eggs for control. Also, decreasing of eggs hatchability was emphasized as it recorded 88.3, 62.5 and $90.3 \%$, respectively in comparison with $100 \%$ in the control. Egg incubation period was elongated to $14,12.7$ and 8.4 days, respectively; while it was only 7.3 days in the control .
Either the life cycle or life span under 2, 4 and 6 pieces of magnets were slightly influenced in comparison of the control. Life cycle recorded 17.8, 14.6 and 12 days compared with 13 days for control. Life span values recorded 28.7, 31.6 and 23.4 days against 30.1 days in the control.

Each of longevity and survivability were negatively influenced with presence of magnets. Period of longevity recorded 10,17 and 14 days under 2, 4 and 6 magnets, respectively in comparison with 17.1 days in the control. The survivability percentage recorded $100,62.5$ and $75 \%$, respectively; while it was $100 \%$ in control. Data also referred to decreasing in T. urticae females numbers as the sex ratio recorded $59.4,60.7$ and $65.2 \%$ in comparison of $85.4 \%$ in control the treatment

In conclusion of our results, we can announce that magnetic fields affect in one way or another biology of the two spotted spider mite T. urticae. As the magnet power increase, the egg hatchability, longevity and mean number of eggs/females/day decrease. Meanwhile; it prolonged incubation period and life cycle compared to the cheek. We suggest that static magnetic field power could be an element of the new approaches represented in the integrated management of $T$. urticae.

\section{REFERENCES}

Aruther, D. R. 2003. Mechanism of moderate - 
intensity static magnetic fields on biological systems Cell Biochem. Bioghys, 39: 162- 173.

Bamathy, J. M. 1963 a. Growth-rate of mice in static magnetic fields. Nature 200: 86-87.

Bamathy, J. M. 1963b. Biological effects of magnetic fields on small mammals. Biomedical Sciences Instrumentation, 1: 127- 136, Plenum Press, New York.

Bamathy, J. M. 1963 c. The effect of a magnetic field upon the growth of young mice, mice embryos and the mammary gland carcinoma of the $\mathrm{C} 3 \mathrm{H}$ strain" (abstr. WE2). Biophys. Soc.

Barnothym, F. 1964. Biological effects of magnetic fields. Publisher: New York.

Bellossi, A. 1986. Effect of static magnetic fields on survival of leukaemia-prone AKR mice. Rariat Environ Biophys, 25: 75-80.

Biljana, S.; Marko, A.; lgor, K.; Iavna, T.; Zlatko, P. and Marina, S. R. 2001. Effect of a permanent magnetic field on wing size parameters in Drosophila melanogaster. Bioelectromagnetics. 22: 365-369.

Brown, F. A. Jr. 1962. Responses of the planarian, dugesia, and the protozoan, paramecium, to very weak horizontal magnetic fields. Biol. Bull., 123: 264-281.

Brown, F. A. Jr. and Webb. H. M. 1960. A compassdirection effect for snails in constant conditions and its lunar modulation. Biol. Bull., 119: 307.

Brown, F.A. Jr. and Hutter, A. 1960. A relationship between photic and magnetic response in snails. Biol. Bull., 119: 306-307.

Brown, F.A. Jr.; Webb, H.M. and Brett, W.J. 1959. Exogenous timing of solar and lunar periodisms in metabolism of the snail, iiyanassa (= Nassarius) obsoleta, in laboratory constant conditions. Gunma J. Med. Sci., 8: 233-242.

Ermakov, A. M. and lednev, V. V. 2010. Effect of weak combined magnetic fields on the metamorphosis of the mealworm beetle Tenebrio molitor Biophysica, J., 55(4): 633-636.

Ginzo, H. D. and Decima, E. E. 1995. Weak static magnetic fields increase the speed of circumnutation in cucumber (Cucumis sativus L.) tendrils. Birkhauser Verlag Basel., 51: 1090-1093.

Giraldo, D. C. and Molina, J. 2013. In seach of magnetosensitivity and ferromagnetic particles in Rhodnius prolixus: behavioral studies and vibrating sample magnetometry. Journal of Insect Physiology, 59(3): 345-350.

Geo, Y. and Zhai, B. 2012. Progress in the mechanisms of insect orientation, Chinese. Bulletin of Entomology, 47(6): 1055- 1065.

Haline, E.; Kong, H. L., and Schumeer, H. 1964. Aphid moulting under controlled electrical condition. Int. J. Biometeor., 7: 265-275.

Hussein, A. M.; Eweis, M. A.; Abdel-Samad, Salwa,
S.M. and Hatem, A. E. 2014. Potential benefits for utilization magnetism in plant protection. Minufiya J. Agric. Res., 39, 1(2): 327-338.

Jihen, T.; Alva, E. M.; Amin, A.; Abdelweheb, C.; Ridha, B. A., and Ahmed, L. 2010. Static magnetic field increases the sensitivity of Salmonella to gentamicin. Ann Microbiol., 60: 519-522.

Jin, Y. L.; Seong, W. K.; Cheol, S.Y.; Jeong, J. K.; Dong, C. R. and Seung, W. K. 2006. Verticilllium Lecanii spore formulation using UVprotectant and wetting agent and the biocontrol of cotton aphids. Biotechnol Lett., 28: 1041-1045.

Juan He, H. H.; Zhao, H. Y.; Monika, W.; Hu, Z.A. and Shun $\mathrm{Hu}, \mathrm{X}$. 2012. Effect of static magnetic fields (SMF) on the viability and fecundity of aphid sitobion avenae (Homoptera: Aphididae) under laboratory conditions. Arch. Biol. Sci., Belgrade, 64(2): 693-702.

Kimball, G.C. 1938. The Growth of Yeast in a Magnetic Field. J. Bacteriol., 35:109-122.

Krylov, V.; Izyumov, Y.G.; Izvekov, E.I. and Nepomny a shchik1, V. A. 2013. Magnetic fields and fish behavior. Zhurnal obshchei Biologi., 74 (5): $354-365$.

Leuch, Th. 1984. Responses to light under varing magnetic conditions in the honeybee, Aphis mellifica. J. Comp . Physiol. A., 154: 865-870.

Levengood, W.C. and Shinkle, M. P.1960. Environmental factors influencing progeny yields in drosophila. Science, 132: 34-35.

Maeda, K.; Henbest, K. B.; Filippo, K. L. and Hore, P. J. 2008. Chemical compass model of avian magnetorecption. Nature, 453(7193): 387- 390.

Martin, H.; Korall, H. and Forster, B. 1988. Magnetic field effects on activity and aging in honeybees. J. Comp physiol., 164: 423-431.

Nabeel, K. A. 2010. Effect of magnetic field on mites. Journal of Al- Nahrain University, 13 (3): 104 109.

Pan, H. J. and Liu, X.H. 2004. Apparent biological effect of strong magnetic field on mosquito egg hatching. Bioelectromagnetics, 25: 84-91.

Paz , H.; Vargas, M. A. ; Forero, O.A. ; Pabon, J. A. and Plaza, J. A. 2012. Local distortion of the earth's magnetic field as a proposal for handing the leafcutter ant species Atta spp. (Hymenopetra: Formicidata). Ingenieria investigation Journal, 32 (2): $28-33$.

Pitman, U. J. 1963. Magnetism and Plant Growth: Effect on germination and early growth of cereal seeds. Can. J. plant Sci., 43: 513-519.

Pitman, U. J. 1964. Magnetism and plant growth: effect on Rppt growth of cereals. Can. J. plant Sci.,44: 211-215.

Rosann, W. M. 2012. Use of electromagnetic fields to affect insect movement. http.// WWW. 
Freepatents online. Com 7712247. html.

Sathon, M.; Tsuji, Y.; Watanabe, Y.; Okonogi, H.; Suzuki, Y.; Nakegawa, M. and Shimizu, H. 1996. Metallothinein content increased in the liver of mice exposed to magnetic fields. Arch Toxicol., 70: 315-318.

Schneider, T.; Thalau, H. P. and Semm, P. 1994. Effects of light or different earth strength magnetic fields on the nocturnal melatonin concentration in a migratory bird. Neurosci., Lett.,
168: 73- 75 .

Wang, W.L.; Ji, X. L.; Wang, G. and Zhou, H. P. 2008. Effects of wheat- oilseed rape or wheat- garlic intercropping on the population dynamics of Sitobion avenae and its main natural enemies. Chinese Journal Applied Ecology, 19: 1331-1336.

Yim, S. H. and Jeong, J. H. 2006. Environmental magnetic fields and its biological effect. Kor. J. Gerontol., 16: 6-10. 